\title{
INTRODUCTION
}

\section{Descent of Darwin: race, sex, and human nature}

\author{
Erika Lorraine Milam ${ }^{1 *}$ and Suman Seth (guest editors) ${ }^{2}$ \\ ${ }^{1}$ Department of History, Princeton University and ${ }^{2}$ Department of Science and Technology Studies, \\ Cornell University \\ *Corresponding author: Erika Lorraine Milam, Email: emilam@princeton.edu
}

\begin{abstract}
In 1871, Charles Darwin published Descent of Man and Selection in Relation to Sex, a text that extended, elaborated and completed his On the Origin of Species (1859). When he had published Origin, Darwin sought, albeit unsuccessfully, to skirt controversy; in Descent he waded into the fray on near-innumerable issues. Readers could find explicit the claim that humans had descended from apes, in addition to explorations of the similarities and apparent gulfs between 'man' and other animals. They also found Darwin's opinions on issues ranging from the origin and hierarchy of races to the question of women's education, from the source of altruistic bravery to the biological importance of aesthetic judgement, from his views on what his cousin would term 'eugenics' to the history of monogamy. In the last 150 years these ideas have been variously contested, rejected and recovered, so that the shadow of Descent extended into debates over the development of languages, the evolution of human sexualities, the ongoing possibilities of eugenics and the question of women's equality. In this volume, appearing during the sesquicentennial of the text's first appearance, one finds papers dedicated to all of these themes and more, laying out the roots and fruits of Darwin's Descent.
\end{abstract}

From the first moments when Charles Darwin began to consider that species might transform over time, he applied his analysis to humans. 'If all men were dead', he wrote in his now-famous 'Transmutation Notebooks' in 1837, 'then monkeys make men'. ${ }^{1}$ And yet, fearing the public backlash with which such claims might be greeted, he did not publish these views immediately. A single line in the conclusion of On the Origin of Species, his most famous work, teased that, via his insights into natural and sexual selection, "light will be thrown on the origin of man and his history', but he said little more in public until a dozen years later. ${ }^{2}$ Then, in The Descent of Man and Selection in Relation to Sex, Darwin would be shockingly direct. 'We thus learn', he wrote, 'that man is descended from a

1 Charles R. Darwin, Notebook B: [Transmutation of Species (1837-1838)], p. 169, transcribed by Kees Rookmaaker, Darwin Online, at http://darwin-online.org.uk (accessed 19 February 2020).

2 Charles Darwin, On the Origin of Species by Means of Natural Selection, or the Preservation of Favoured Races in the Struggle for Life, London: John Murray, 1859, p. 488. Throughout the nineteenth century and much of the twentieth, scientists comfortably used 'man' to refer to the evolutionary lineage culminating in modern humanity. Not until the third quarter of the twentieth century did the use of 'human' become widespread in zoology and anthropology. Virginia L. Warren, 'Guidelines for the nonsexist use of language', Proceedings and Addresses of the American Philosophical Association (1986) 59, pp. 471-84.

(c) The Author(s), 2021. Published by Cambridge University Press on behalf of British Society for the History of Science. This is an Open Access article, distributed under the terms of the Creative Commons Attribution-NonCommercial-NoDerivatives licence (http://creativecommons.org/licenses/by-nc-nd/4.0/), which permits non-commercial re-use, distribution, and reproduction in any medium, provided the original work is unaltered and is properly cited. The written permission of Cambridge University Press must be obtained for commercial re-use or in order to create a derivative work. 
hairy quadruped, furnished with a tail and pointed ears, probably arboreal in its habits, and an inhabitant of the old World'.

While a few complimentary copies, including Darwin's own, were printed in 1870, the two volumes of the Descent were published for purchase on 24 February 1871. The publisher was the prestigious John Murray of London, the third of that name to own the house since its founding in 1768. As an advertisement just before the contents page noted, Murray had previously published Darwin's On the Origin of Species (the fifth edition of which had appeared in 1869), The Variation of Animals and Plants under Domestication (1868), On the Various Contrivances by which British and Foreign Orchids Are Fertilised by Insects (1862), and the second edition of the Journal of Researches into the Natural History and Geology of the Countries Visited during the Voyage of H.M.S. Beagle around the World (1845). An initial issue of 2,500 copies was quickly supplemented by a second, in March, of two thousand, each at a cost of $£ 1$ 4s. It would be the first of Darwin's books to make a 'handsome publishing profit': at the end of September, Murray sent the pleased author a cheque for $£ 1,470$. $^{4}$

Volume 1, running to over 420 pages, covered the entirety of 'Part 1: on the descent of man' and four chapters of 'Part 2: sexual selection', while Volume 2, longer by some fifty pages, included the remaining ten chapters and the index. The texts were illustrated by seventy-six woodcuts, marking an obvious visual contrast to the Origin, which had famously contained only a single, branching tree diagram. A second, much altered edition appeared in 1874, now bound as a single volume in three parts. It continued to sell well, with the 35,000th issue of the Murray text appearing in 1899. The year of its first English publication also saw translations into Dutch, German, Russian and Italian, with later translations into French, Danish, Polish and Swedish in Darwin's lifetime and more than a dozen other languages since. As R.B. Freeman noted in 1977, this included two distinct translations into Yiddish - one American, one Polish - at the time at least 'the only Darwins in this language'.

Darwin awaited reviews and responses to the work with trepidation, anticipating, he claimed, 'universal disapprobation'. The problem was not, as even he admitted in the introduction to the text, the mechanism behind the main theory he had described in Origin. 'The greater number' of naturalists, he claimed (and the large majority of the younger generation in particular), 'accept the agency of natural selection'.7 The sticking point would be the application of his logics to the descent of man, in particular. Yet, as Moore and Desmond have pithily observed, 'few howls were heard, merely muffled growls'. ${ }^{8}$ Darwin himself suggested in March 1871 that the fact Descent had 'sold wonderfully' was 'proof of the increasing liberality of England'. He had, as yet, faced 'no abuse', although, as he added parenthetically, ‘some, no doubt, will come, strong enough'. He

3 Charles Darwin, The Descent of Man and Selection in Relation to Sex, London: John Murray, 1871, vol. 2, p. 389. See also James Moore and Adrian Desmond, introductory material to Charles Darwin, Descent of Man, London: Penguin Books, 2004.

4 Janet Browne, Charles Darwin: The Power of Place, Princeton, NJ: Princeton University Press, 2002, p. 350.

5 R.B. Freeman, The Works of Charles Darwin: An Annotated Bibliographical Handlist, 2nd edn, Folkstone: Wm Dawson and Sons, 1977, pp. 128-33, 131.

6 James Moore and Adrian Desmond, 'Introduction', in Charles Darwin: The Descent of Man and Selection in Relation to Sex, London: Penguin, 2004, p. xv.

7 Charles Darwin, The Descent of Man, and Selection in Relation to Sex, facsimile of the 1st edn (1871), Princeton, NJ: Princeton University Press, 1981, p. 2. That said, it would be precisely one of these younger naturalists who would pen the most devastating review of the Descent. St George Mivart, '[Review of] The Descent of Man and Selection in Relation to Sex', Quarterly Review (1871), 131, pp. 47-90. On Darwin's response to the review see Browne, op. cit. (4), pp. 353-6.

8 Moore and Desmond, op. cit. (3) p. li. 
found, it is true, few sympathetic reviewers for his claims concerning humanity's descent from a lower life form. That other animals were related to one another might be granted, but man was a special case. Reviewers in The Times, Harper's Weekly, the Edinburgh Review, The Spectator and multiple other journals seemed in accord with a writer in The Guardian, who simply asserted that 'Holy Scripture plainly regards man's creation as a totally distinct class of operations from that of lower beings.'

Overall, however, the dozen years of public battles over evolution that had followed the publication of Origin meant that the response to Descent was more muted than it might once have been. 'Apes and angels had been dealt with ten or twelve years before', Janet Browne notes. 'Faced with a new book about descent in 1871, journalists seemed to find little more to say. They and their readers had become accustomed to the idea of evolution, although not necessarily comfortable with it. ${ }^{10}$ That discomfort would persist, for Darwin's Descent did much more than simply apply the logics of Origin to humanity. In one of the most insistently - and at times perversely - naturalistic books of the nineteenth century, he sought to establish that all aspects of humanity have some parallel in lower species. Where many of Darwin's contemporaries could grant that 'man' shared his physical form with members of the animal kingdom, they also insisted that humans differed in their intellects and souls. Darwin resisted even this separation. Beasts could think, he posited, could appreciate the rudiments of aesthetics, and could engage in altruistic acts. Animals even exhibited some form of religious understanding. There was no space in Darwin's work for a creator to make a distinction of kind, rather than degree, amongst the myriad of his creations. ${ }^{11}$

In Descent, too, Darwin explicitly drew upon the social mores of his age, naturalizing Victorian assumptions concerning class, race and sex. ${ }^{12}$ The dismal vision of the British political economist Thomas Malthus had provided an engine driving natural selection: in a population under severe pressure for resources, the 'fittest' - in Herbert Spencer's later formulation - would survive in disproportionate numbers. In Descent, Darwin made clear that he shared at least parts of Malthus's moralizing social vision as well. 'The advancement of the welfare of mankind', he wrote, 'is a most intricate problem: all ought to refrain from marriage who cannot avoid abject poverty for their children; for poverty is not only a great evil, but tends to its own increase by leading to recklessness in marriage.. ${ }^{13}$

Race was a hinge connecting the two parts of Darwin's book: one on human descent, one on sexual selection. For Darwin, differences between the races were not originary.

9 Browne, op. cit. (4), pp. 350-1, 351.

10 Browne, op. cit. (4), pp. 351.

11 E.g. Peter Bowler, Theories of Human Evolution: A Century of Debate, 1844-1944, Baltimore: Johns Hopkins University Press, 1986; James Secord, Victorian Sensation: The Extraordinary Publication, Reception, and Secret Authorship of Vestiges of the Natural History of Creation, Chicago: The University of Chicago Press, 2000; Gregory Radick, The Simian Tongue: The Long Debate about Animal Language, Chicago: The University of Chicago Press, 2007; Adrian Desmond and James Moore, Darwin's Sacred Cause: Race, Slavery and the Quest for Human Origins, London: Allen Lane, 2009; Suman Seth, 'Darwin and the ethnologists: liberal racialism and the geological analogy', Historical Studies in the Natural Sciences (2016) 46, pp. 490-527; Evelleen Richards, Darwin and the Making of Sexual Selection, Chicago: The University of Chicago Press, 2017; Efram Sera-Shriar (ed.), Historicizing Humans: Deep Time, Evolution, and Race in Nineteenth-Century British Sciences, Pittsburgh: University of Pittsburgh Press, 2018.

12 Richards, op. cit. (11); Cynthia Eagle Russett, Sexual Science: The Victorian Construction of Womanhood, Cambridge, MA: Harvard University Press, 1989.

13 Darwin, op. cit. (3), p. 403. See also Robert Young, Darwin's Metaphor: Nature's Place in Victorian Culture, Cambridge: Cambridge University Press, 1985; Daniel Todes, Darwin without Malthus: The Struggle for Existence in Russian Evolutionary Thought, Oxford: Oxford University Press, 1989; Mark Francis, Herbert Spencer and the Invention of Modern Life, Chesham: Acumen, 2007; Piers Hale, Political Descent: Malthus, Mutualism, and the Politics of Evolution, Chicago: The University of Chicago Press, 2014. 
Against those who argued that humans developed (or were created) in different kinds (and hence that Africans, for example, were not to be regarded as 'brethren' to Europeans), Darwin concluded that we were all one, even if he demurred on the claim that humans found their beginnings in a single, Edenic pair. This monogenetic insistence, however, raised new questions. Whence the physical differences between human races? Why were some peoples dark-skinned with black, curly hair, while others were fair and blonde? Darwin rejected the kinds of answers we accept today, arguing that natural selection was insufficient for explaining why some groups of humans at similar latitudes did not exhibit the same skin colour, while those at geographically dispersed latitudes looked remarkably similar. Nor could he establish an adaptive advantage for other racial traits. What kind of 'fitness' could be associated with the European male's bushy beard, among the most oft-remarked-upon differences among so-called Caucasians and Negro or Malayan races? Instead - as Evelleen Richards has so elegantly elucidated in Darwin and the Making of Sexual Selection - Darwin argued that selection on the idiosyncratic aesthetic predilections of men and women of all races had produced such differences. ${ }^{14}$ Women in some isolated European populations over vast spans of time had preferred men with hirsute visages, while aesthetic preferences had gone the other way on the African and Asian continents. Natural selection might explain how we, as a species, came to be distinguished from apes, but it was differential conceptions of beauty that explained how we differed from each other. The association of Darwin with evolutionary theories of human unity and difference spread like wildfire. ${ }^{15}$

The production, reception and legacy of Charles Darwin's Descent of Man and Selection in Relation to Sex (1871) are marked by scientists' direct engagement with questions of race, sex, class and sexuality - in essence, those familiar characteristics which were taken to mark humanity. ${ }^{16}$ Whether in spite or because of Darwin's own clear and fascinating borrowings from the social realm, Descent has received much less scholarly attention than Origin; the materials that make up the extensive Darwin literature are concerned primarily with the production and reception of Darwin's theory of natural, rather than sexual, selection. ${ }^{17}$ In the last decade, sexual selection has piqued scientific and historical interest, drawing on long-standing scholarship exploring the naturalization of sex and race. ${ }^{18}$

14 Richards, op. cit. (11). On Victorian aesthetics, sex and race see Ann B. Shteir and Bernard Lightman (eds.), Figuring It Out: Science, Gender, and Visual Culture, Hanover, NH: Dartmouth College Press, 2006; Jonathan Smith, Charles Darwin and Victorian Visual Culture, Cambridge: Cambridge University Press, 2006; Sadiah Qureshi, Peoples on Parade: Exhibitions, Empire, and Anthropology in Nineteenth-Century Britain, Chicago: The University of Chicago Press, 2011.

15 Literary historians have demonstrated the influence of Descent on later Victorian writers, especially on tropes of courtship. See, for example, Gillian Beer, Darwin's Plots: Evolutionary Narrative in Darwin, George Eliot and Nineteenth-Century Fiction, 3rd edn, Cambridge: Cambridge University Press, 2009; Bert Bender, The Descent of Love: Darwin and the Theory of Sexual Selection in American Fiction, 1871-1926, Philadelphia: University of Pennsylvania Press, 1996; Bender, Evolution and 'the Sex Problem': American Narratives during the Eclipse of Darwinism, Kent, $\mathrm{OH}$ and London: Kent State University Press, 2004; William Greenslade and Terence Rodgers (eds.), Grant Allen: Literature and Cultural Politics at the Fin de Siècle, London: Routledge, 2005; Gowan Dawson, Darwin, Literature and Victorian Respectability, Cambridge: Cambridge University Press, 2007. See also George Stocking Jr, Victorian Anthropology, London: Collier, 1987; Paul Farber, Mixing Races: From Scientific Racism to Modern Evolutionary Ideas, Baltimore: Johns Hopkins University Press, 2011.

16 Donna Haraway, Primate Visions: Gender, Race, and Nature in the World of Modern Science, New York: Routledge, 1989; Qureshi, op. cit. (14); Banu Subramaniam, Ghosts of Darwin: The Science of Variation and the Politics of Diversity, Urbana: University of Illinois Press, 2015.

17 Gillian Beer reflects on this in her introduction to Beer, op. cit. (15), p. xxiv.

18 As the history of the life sciences expanded in the last quarter of the twentieth century, scholarship has increasingly attended to the similarities of processes that naturalize claims of biological identity, whether crafted in the language of race, sex, sexuality, disability or even age - an umbrella referent for such processes might deem them 'biologically determinist' or even 'dehumanizing'. See, e.g., Londa Schiebinger, The Mind Has No 
Much of this literature has tackled questions of either sex and gender or race and human descent, yet, as Richards's Darwin and the Making of Sexual Selection so clearly shows, for Darwin these questions were mutually constitutive. ${ }^{19}$ In her analysis, Darwin's experience on board the HMS Beagle launched him on a quest to understand the naturalistic process governing the development of aesthetic preferences in humans and animals - at issue were the relative standards of beauty held by racialized groups. ${ }^{20}$ He first used the term 'sexual selection' in his notes as he grappled with Robert Knox's Races of Men. ${ }^{21}$ Although he had planned to include substantial material on sexual selection in his 'big species book', when he rushed Origin into print he whittled his discussion of mate choice and competition down to a single chapter, which enabled him to postpone until later what would become Descent - his discussion of human evolution. ${ }^{22}$ By bringing together historians invested in the history of evolution, race, sex and human nature, this volume explores the forest of interpretations that have grown from these Darwinian seeds in the last century and a half.

In the years since 1871, scientists and scholars around the globe have debated and deployed Darwin's Descent in myriad contexts. From the woman question of the late nineteenth century to the concerns of evolutionary psychology in the late twentieth, scientists have continued to utilize Darwin's writings as an intellectual resource in seeking answers to questions of humanity's essential nature. Over the course of the intervening century, Darwin's theories served to explain and naturalize differences across the political

Sex? Women in the Origins of Modern Science, Cambridge, MA: Harvard University Press, 1989; Russett, op. cit. (12); Keith Wailoo, Dying in the City of the Blues: Sickle Cell Anemia and the Politics of Race and Health, Chapel Hill: University of North Carolina Press, 2001; Lorraine Daston and Fernando Vidal (eds.), The Moral Authority of Nature, Chicago: The University of Chicago Press, 2004; Helen Longino, Studying Human Behavior: How Scientists Investigate Aggression and Sexuality, Chicago: The University of Chicago Press, 2013; Sarah Richardson, Sex Itself: The Search for Male and Female in the Human Genome, Chicago: The University of Chicago Press, 2013; Lorraine Daston, Against Nature, Cambridge, MA: MIT Press, 2019. Scholarship from critical race and gender studies has established that the effects of such hierarchies intersect to the legal detriment of people who are multiply marginalized: Kimberlé Crenshaw, 'Demarginalizing the intersection of race and sex: a black feminist critique of antidiscrimination doctrine, feminist theory, and antiracist politics', University of Chicago Legal Forum, 1989, article 8, pp. 139-67; Barbara Jeanne Fields, 'Slavery, race and ideology in the United States of America', New Left Review (1990) 181, pp. 95-118; Evelyn Brooks Higgenbotham, 'African-American women's history and the metalanguage of race' (1992) 17, pp. 251-74. Race, in these analyses, continues to exist because it is continuously reified as socially important - the same can be said of any other category of social demarcation rendered in biological language. Historians of science, technology and medicine have begun to bring these two perspectives together. Keith Wailoo, Alondra Nelson and Catherine Lee (eds.), Genetics and the Unsettled Past: The Collision of DNA, Race, and History, New Brunswick, NJ: Rutgers University Press, 2012; Kimberly TallBear, Native American DNA: Tribal Belonging and the False Promise of Genetic Science, Minneapolis: University of Minnesota Press, 2013; Alonda Nelson, The Social Life of DNA: Race, Reparations, and Reconciliation after the Genome, Boston: Beacon Press, 2016; Myrna Perez Sheldon and Projit Bihari Mukharji (eds.), 'Open conversations: diversifying the discipline or disciplining diversity?', Isis (2020) 111, pp. 310-53, with contributions by each editor, as well as Elise K. Burton, Sebastián Gil-Riaño, Terence Keel, Emily Merchant, Wangui Muigai, Ahmed Ragab and Suman Seth. This volume draws on this scholarly conversation in taking as a key aim the deconstruction of race, sex and human nature as objects naturalized by evolutionary theories, to show how these social categories vary in temporal and spatial flux.

19 Richards, op. cit. (11); regretfully Evelleen Richards was unable to contribute to this volume. See also Erika Lorraine Milam, Looking for a Few Good Males: Female Choice in Evolutionary Biology, Baltimore: Johns Hopkins University Press, 2010; Kimberly Hamlin, From Eve to Evolution: Darwin, Science, and Women's Rights in Gilded Age America, Chicago: The University of Chicago Press, 2014; Thierry Hoquet (ed.), Current Perspectives on Sexual Selection: What's Left after Darwin? London: Springer, 2015; Richard Prum, The Evolution of Beauty: How Darwin's Forgotten Theory of Mate Choice Shapes the Animal World - and Us, New York: Doubleday, 2017.

20 Richards, op. cit. (11), pp. 3-34.

21 Richards, op. cit. (11), p. 314; Robert Knox, The Races of Men: A Fragment, London: H. Renshaw, 1850.

22 Richards, op. cit. (11), pp. 331-69. 
spectrum. Eugenicists and others pointed to women and people racialized as non-white as less evolved or evolved differently. Progressive Era feminists invoked female choice to argue that they should be given more social responsibility than men, not less.

The idea that humans had evolved from ape-like ancestors, too, remained intimately associated with Darwin's name, even though he was neither the first nor the most recent naturalist to discuss the 'descent' or (more frequently) 'ascent' of man. ${ }^{23}$ Other scientists, however, quickly abandoned his notion that sexual selection had created human 'races' and instead associated human evolution with the theory of descent, or organic evolution, broadly conceived. Sexual and natural selection as applied to human nature did stick in two ways: in interpreting differences between the sexes and in the possibility of controlling humanity's future, both of which depended on mate choice. ${ }^{24}$ That Darwin had engaged explicitly with questions of race, sex and class in human evolution indelibly linked these ideas with his name but not necessarily with Descent, and provided leverage for differentiating between the modern and the uncivilized. ${ }^{25}$ By tracing the appropriation of Darwin's ideas, the essays in this volume make evident the crucial role played by Descent even when authors cited Origin as the key reference to Darwin's understanding of race, animality, sex and human nature.

Three essays explore the creation and reification of racial categories as a function of Darwinian theory. In the careful attention paid to the reproduction of enslaved people and contemporary theories of hybridization, issues of sex and race were bound intimately to each other long before Darwin published Descent. Myrna Perez Sheldon argues that Darwin transformed this connection into causality, seeing sexual reproduction as a mechanism explaining the origins of races. Thus sex became as integral to evolutionary

23 The extensive historiography on palaeo-anthropology includes Bert Theunissen, Eugène Dubois and the Ape-Man from Java: The History of the First Missing Link and Its Discoverer (tr. E. Perlin-West), Dordrecht: Kluwer Academic Publishers, 1989; Misia Landau, Narratives of Human Evolution, New Haven, CT: Yale University Press, 1991; Marianne Sommer, Bones and Ochre: The Curious Afterlife of the Red Lady of Paviland, Cambridge, MA: Harvard University Press, 2007; Richard G. Delisle, Debating Humankind's Place in Nature, 1860-2000: The Nature of Paleoanthropology, Upper Saddle River, NJ: Pearson Prentice Hall, 2007; Matthew Goodrum, 'The history of human origins research and its place in the history of science: research problems and historiography', History of Science (2009) 47, pp. 337-57; B. Ricardo Brown, Until Darwin: Science, Human Variety and the Origin of Race, London: Pickering \& Chatto, 2010; Adriana Novoa and Alex Levine, From Ape to Man: Darwinism in Argentina, 1870-1920, Chicago: The University of Chicago Press, 2010; Sigrid Schmalzer, People's Peking Man: Popular Science and Human Identity in Twentieth-Century China, Chicago: The University of Chicago Press, 2008; Marianne Sommer, History Within: The Science, Culture, and Politics of Bones, Organisms, and Molecules, Chicago: The University of Chicago Press, 2016; Christa Kulijian, Darwin's Hunch: Science, Race, and the Search for Human Origins, Johannesburg: Jacana Media, 2016; Matt Goodrum, 'The beginnings of human paleontology: prehistory, craniometry, and the "fossil human races", BJHS (2016) 49, pp. 387-409; Erika Lorraine Milam, Creatures of Cain: The Hunt for Human Nature in Cold War America, Princeton, NJ: Princeton University Press, 2019.

24 Mark Adams (ed.), The Wellborn Science: Eugenics in Germany, France, Brazil, and Russia, New York: Oxford University Press, 1990; Diane Paul, Controlling Human Heredity, 1865 to the Present, Atlantic Highlands, NJ: Humanities Press, 1995; Molly Ladd-Taylor, 'Eugenics, sterilisation and modern marriage in the USA: the strange career of Paul Popenoe', Gender \& History (2001) 13, pp. 298-327; Angelique Richardson, Love and Eugenics in the Nineteenth Century: Rational Reproduction and the New Woman, Oxford: Oxford University Press, 2003; Milam, op. cit. (19); Hamlin, op. cit. (19); Marion Thomas, 'Are women naturally devoted mothers? Fabre, Perrier, Giard and animal maternal instinct in Third Republic France', Journal of the History of the Behavioral Sciences (2014) 50, pp. 280-301; Susan Rensing, “"Falling in love intelligently": eugenic love in the Progressive Era', Journal of Popular Romance Studies (2015) 5, pp. 1-19; Myrna Perez Sheldon, 'Wild at heart: how sociobiology and evolutionary psychology helped influence the construction of heterosexual masculinity’, Signs (2017) 42, pp. 977-98.

25 On contestations over modernity in epic time see Cathy Gere, Knossos and the Prophets of Modernism, Chicago: The University of Chicago Press, 2009; Robert Brain, The Pulse of Modernism: Phsyiological Aesthetics in Fin-de-Siècle Europe, Seattle: University of Washington Press, 2015; Nasser Zakariya, A Final Story: Science, Myth, and Beginnings, Chicago: The University of Chicago Press, 2017; and Stefanos Geroulanos and Maria Stavrinaki (eds.), 'Writing prehistory', Res: Anthropology and Aesthetics (2018) 69-70, pp. 1-268. 
theories as it was to the governing principles of modern nation states. Suman Seth picks up this thread, exploring how Darwin's theory of racial construction came only after he eliminated other possibilities, especially the idea that dark skin could be correlated with certain kinds of disease immunity. In the nineteenth century, Seth contends, medicine was a crucial site for forging ideas about race. Among the questions Darwin considered most deeply was that of the single or multiple origins of the human species. ${ }^{26}$ Marianne Sommer shows that the high stakes of this debate informed Descent's visual language as well as its prose. As noted earlier, Descent was generously illustrated, reflecting the rich nineteenth-century visual culture depicting sexualized and racialized subjects for public consumption. Darwin had intended that one of these figures would depict the evolutionary relationships between primates. In the end, Darwin decided against including it, and Sommer posits in her paper that his reluctance stemmed from the image's concrete representation of an abstract set of relationships. Once printed, he feared, it would imply racial hierarchies and an inherent teleology he was keen to avoid. Race suffused Darwin's understanding of sex and history, as Sheldon, Seth and Sommer amply demonstrate.

Sexual selection, for Darwin, explained as much about animals as it did about humans, by illustrating their deeply entwined fates. In his paper, Projit Bihari Mukharji explores Darwin's fascination with the diversity of South Asian birds and the ways that sexual selection emerged from the colonial realities of ornithology. Information about birds flowed along the routes of imperial travel, taken from Victorian India and transformed into data. Gregory Radick and Mark Steadman attend to voyages of a different sort, starting with the men and lice on board the HMS Beagle. For Darwin, the apparent association of different species of lice with different races provided a platform for working through the relationship between varieties and species identity. In light of these slippages between humanity and animality, the capacity for true language remained a key dividing line. Judith Kaplan explores how linguists sought to understand the origins of language in human history, rendering this distinction equally porous in the evolutionary linguistics of the Cold War.

Returning to the turn of the century, Kimberly Hamlin argues that Darwin's ideas in Descent - about sex, race and human evolution - found fertile intellectual ground among radical freethinkers, socialists and feminists. Their fascination with and appropriation of Darwin's ideas, Hamlin suggests, served to make them appear even more scurrilous to the scientific establishment and help account for the lack of citations of Descent, even as biologists themselves continued to wrestle with the same ideas and concepts. In attending to questions of sexuality, Erika Lorraine Milam then explores how evolutionary biologists of the late twentieth century applied evolutionary theories to the origin of homosexuality as a biological phenomenon. For most of the century, she argues, these theories relied on comparisons between humans and a finite number of animal species; however, more recently arguments for marriage equality have emphasized the diversity of sexualities across the animal kingdom. Together, Hamlin's and Milam's papers illustrate the power that Darwin's theories in Descent held for scientists and activists seeking to make sense of their contemporary society.

The final set of papers turns to human nature, with Piers Hale tackling the question of Darwin's politics, and especially how sexual selection underpinned Darwin's writings on the origins of other-regarding ethics in humans. Although Darwinism has often been associated with theories of racism and sexism, Hale argues, there is a tradition, too, in finding in Darwin's theories the promise of moral worth in all sentient beings, human and non-human alike. Nasser Zakariya unearths the ways in which the evolutionary process - for authors in the 1870s and beyond - represented a compromise of antagonistic forces:

26 Desmond and Moore, op. cit. (11). 
natural and sexual selection, ethics and survival, morality and intelligence. Resolving these forces required reconciling conflicting notions of progress that shifted with political and historical context. Such negotiations also characterized the reception of ideas about reproduction, eugenics and human evolution in China, as charted by Lijing Jiang. She shows how a prominent eugenicist and an embryologist keen to improve the Chinese race and nation argued for the application of evolutionary theory to humanity but downplayed Descent in their publications.

In sum, the social and intellectual influence of Descent of Man and Selection in Relation to Sex far exceeded direct citations of and references to Darwin's work by the scientific community. Indeed, sexual selection remains a powerful logic through which scientists today seek to make new sense of the raced, sexed and classed world in which they live. ${ }^{27}$ Darwin's obsessions are ours too. To fully grasp the long-term perceived relevance of these ideas to our modern understandings of what makes us human, we must wrestle with the polymorphous political flexibility of evolutionary theories of humanity. Yes, evolutionary theory has been used to separate people and reify difference in biological language - we know this story well - but scientists and social activists alike have also mobilized evolution in the service of progressive, even radical, political stances. Together the essays of this volume powerfully illustrate this diversity, allowing us to see, with the benefit of historical hindsight, the impossibility of reducing any biological insight to a single social interpretation. Power, hope and danger all lurk in the naturalizing promise of evolutionary understandings of human behavior.

Acknowledgements. It is an enormous pleasure to thank the contributors to this volume, as well as the participants in the Descent of Darwin conference, held in Princeton, 9-10 February 2018, sponsored by Princeton University's Program in the History of Science, the Center for Collaborative History, the University Center for Human Values, and Gender and Sexuality Studies. Simon Werrett has been an exemplary editor and we are deeply in Trish Hatton's debt for all of her work in getting every paper through to publication. We have also benefited from the generous and generative comments of our anonymous reviewers. Sincere thanks to all.

27 E.g. Elizabeth Grosz, Becoming Undone: Darwinian Reflections on Life, Politics, and Art, Durham, NC: Duke University Press, 2011; Prum, op. cit. (19); Michael Ryan, A Taste for the Beautiful: The Evolution of Attraction, Princeton, NJ: Princeton University Press, 2018; cf. Joan Roughgarden, The Genial Gene: Deconstructing Darwinian Selfishness, Berkeley: University of California Press, 2009.

Cite this article: Milam EL, Seth S (guest editors) (2021). Descent of Darwin: race, sex, and human nature. BJHS Themes 6, 1-8. https://doi.org/10.1017/bjt.2021.9 